DOI: 10.53477/2668-2001-21-42

\title{
SPECIFICS OF FOREIGN LANGUAGE EDUCATION OF MILITARY PERSONNEL THROUGH THE EXAMPLE OF THE ARMED FORCES OF THE SLOVAK REPUBLIC
}

\author{
Eva Révayová ${ }^{1}$ \\ Armed Forces Academy of General Milan Rastislav Štefánik
}

\begin{abstract}
This paper deals with the specifics of the teaching and learning processes of a foreign language for military purposes. Members of the armed forces not only communicate differently than civilians, but they also learn differently. The theoretical considerations are supported by examples from the teaching/learning processes within military environment. It emphasizes the military significance of language competence and examines the role of multilingualism within NATO and EU armies.
\end{abstract}

Keywords: foreign language; armed forces; military education; specifics of military language education; multilingualism.

\section{INTRODUCTION}

Language skills have always been an integral part of the key military competencies. Although foreign language competence has long been quite stereotypically linked with the category of military intelligence, the (geo)political events over the recent decades have made it obvious, that a (very) good foreign languages command is significant in all branches and on all levels of the military, reaching from the education, leadership, diplomacy to the war. The following excerpt from the 2009 Army Culture and Foreign Language Strategy expresses this fact in the following way: "Battlefield lessons learned have demonstrated that language proficiency and understanding of foreign culture are vital enablers for full spectrum operations. Today's full spectrum operations require adaptable foreign language and cultural capabilities to be fully successful."

\section{MULTILINGUALISM WITHIN NATO AND EU}

Soldiers of armies around the world benefit from the command of foreign languages. Foreign language policy has always been important at NATO due to its impact on interoperability. Mark Crossey argued: "Since the end of the Cold War, foreign language training - especially the learning of English, the de facto operational language - has become increasingly important within armed forces." (2008). He added that although language training should be primarily a national responsibility, it must be of concern to NATO regarding the enlargement, foreign operations, international partnerships, and other challenges. Language levels, requirements and assessment of language levels are regularly addressed within NATO internal documents, conferences on terminology management, and NATO Standardization Office.

Language learning is an important priority within the European Union. It's language policy is based on the famous motto "united in diversity“, which first came into use in 2000 and expresses the harmonious co-existence of the many European languages. On one hand EU values the uniqueness and inheritance of its individual languages, on the other hand it encourages the study of at least two foreign languages. English as lingua franca can open doors regarding employment, negotiations, research, travel, business etc., but EU especially promotes the "learning the neighbor's language“ policy. In his September 2007 speech, the former European Commissioner responsible for

\footnotetext{
${ }^{1}$ Corresponding author: Eva.Revayova@aos.sk
} 
Multilingualism - Leonard Orban (2007) - said: "Our aim is to give the Union a new generation of multilingual citizens". He held the view that good command of English is increasingly becoming not sufficient and that in order to be effective, language learning should meet at least 3 criteria: it should be attractive, it should start at an early age, and it should continue during one's whole life.

There are several different types of multilingualism. Regarding the language skills, the EU refers to multilingualism as "both a person's ability to use several languages and the co-existence of different language communities in one geographical area"(5). There have been many efforts in the area of language education policy to support language education and multilingualism with the EU, e.g. the position of the European Commissioner for Education, Culture, Multilingualism and Youth, the European Day of Languages, Erasmus programs, conferences on linguistics and multilingualism and many other activities to promote language learning.

From the historical point of view, multilingualism in the European area is not a novelty and definitely not unusual. Medieval Europe's citizens were multilingual due to the religion (pilgrimages, liturgical language), trade, changes of rulers etc. In fact, monolingualism is characteristic only of a minority of the world's peoples (Guadalupe). Although multilingualism has received special scholarly attention just in recent years, it is a very common phenomenon. Its social, career and cognitive benefits have been widely recognized through many studies, it even improves learning abilities, changes neurological processes, influences decision-making skills and generally speaking, it is simply great for the brain.

\section{LANGUAGE EDUCATION AT THE ARMED FORCES ACADEMY OF GENERAL MILAN RASTISLAV ŠTEFÁNIK}

Over the last 15 years there have been several major changes in the foreign language education concept at the Armed Forces Academy of gen. M. R. Štefánik in Liptovský Mikuláš (henceforth the AFA). The year 2007 was the last year when the applicants could choose either English or German as the foreign language entrance exam. ${ }^{2}$ Since then, English has been the only option for the foreign language entrance exam. This was also the year, when a second foreign language (German or Russian) ceased to be taught within all study programs.

After Slovakia joined the NATO in 2004, the focus has for obvious reasons been on the English language. All NATO member states, including Slovakia, have sought to develop proper English as Second Language (henceforth ESL) methodologies and language education strategies. Regarding the foreign language education within the Slovak Armed Forces this has had a huge impact on the second foreign language policy. As has just been mentioned, the cadets of AFA no more had the opportunity to study German or Russian. In addition to it, German language STANAG exams have ceased to be conducted over some time. French has never been taught at the AFA, while being one of the official languages of NATO. Taking into account the fact that Russian is the most spoken native language in Europe, followed by German, this has launched an unfavorable development.

In 2014 the second foreign language was reintroduced at the AFA, though just in one of the study programs of the master study, that is to say in the 4th and 5th year of study. Since then, the cadets may opt for German or Russian. At present, English is studied in all study programs of the master degree as the first foreign language, starting with the first term and ending after the fifth term by passing the NATO STANAG 6001 exam. Cadets should preferably pass level 2/2/2/2, however, currently it is not obligatory, so a certain percentage of them pass level 1 or $1+$, and similarly a certain number of them pass level $3 / 3 / 3 / 3$.

However, we are not talking here about conventional English language education. In the context of the Armed Forces Academy we should more particularly talk about Military English. Cadets are familiarised with the basic military vocabulary right from the beginning of their study, starting with topics like bootcamp, organization and structure of the army, army ranks, military education and

\footnotetext{
2 The opportunity to opt for English or German as the foreign language entrance exam had been understandable given the significant number of applicants without any knowledge of English. This was due to the multitude of elementary and high schools teaching foreign languages other than English (mostly German, Russian and French).
} 
career ladder, uniform and equipment, military routines, briefing, vehicles and weapons, shooting range, map reading, tactics, military exercises, radio talk, armed conflicts, peace support operations etc. Advanced students' topics include cyber security, casualty evacuation, civil-military cooperation (CIMIC), leadership, operations order (OPORD), laws of armed conflict, formal emails, military doctrine, foreign affairs etc. In addition to the military vocabulary, cadets study current events, grammar, they do reading and comprehension and listening and comprehension activities and learn to write properly and speak fluently.

The second foreign language education also includes some military topic, although not as many as Military English lessons. The level of command of a second foreign language in cadets tends to be significantly lower than the level of the first foreign language, which in most cases is English. Regarding the Russian language at AFA, there are currently three levels being taught: beginner, intermediate and upper-intermediate. German language is taught in two levels: beginner, intermediate. Current developments suggest, that in the next academic year, there will also be an upper-intermediate level of German classes.

In contrast to other technical languages, military languages are not typically being researched much by linguists and as a result, there is a lack of teaching material and apparent scarcity of specialized literature. This is partially due to the nature of communication within the military, which is typically marked by a certain level of security classification, and partially due to the complexity of a military language. Thus, foreign teachers at the AFA are challenged in their everyday teaching tasks to develop proper methods, materials and approaches for cadets to reach their aims, improve their levels of foreign languages command and acquire knowledge in areas like military terminology.

\section{FOREIGN LANGUAGE FOR MILITARY PURPOSES}

The language that is being communicated within the armed forces is a very complex phenomenon. It is shaped by many factors including the political systems of the concrete individual states, geopolitics, partnerships, memberships in international organizations etc. Regarding the languages relevant for this article, i.e. the English, German, and Russian language, the way one should communicate within the military is constantly being re-considered, modified, debated, and dictated by the individual armed forces and the NATO (Slater 2015, 2).

Joining the army means walking into a new linguistic world. Once there, one might get lost without the proper military background knowledge. Aside from the acronyms and abbreviations, members of the military have a myriad of special phrases that set them apart from the rest of the society. This type of language may be defined as the military jargon or slang and it's typical characteristics include uniqueness, the aspect of humor, friendship, but also cynicism and vulgarity. It reflects the interservice and interpersonal rivalries, it boosts the team spirit.

Apart from the military jargon we distinguish between the specialized (or technical) military terminology, official military terminology (inevitable for eliminating misunderstandings that could possibly lead to catastrophe and for optimizing operation under great stress), drill commands (Kommandosprache in German), and the language used by military officers (Offizierssprache in German; surprisingly, there is no proper English term for it). There is also a big difference in stylistics, vocabulary and even grammar between the language that is used exclusively within the military and the language used by the military, but in a dialogue with a non-military environment, e.g. with the press, politicians or simply put, with the public. According to Cori Dauber, official military language manifests at least three special features that can be revealed through linguistic analysis. Those would be: a sanitized form of language, emphasis on expertise of users, and a specific notion of hierarchy. Some examples of typical features of military language are: euphemistic aspect, linguistic economy, neologisms, occasionalisms, informal use of metaphors (especially with names / codenames; Dauber uses the term "internal symbolic logic"), etc. 


\section{SPECIFICS OF LANGUAGE EDUCATION AT THE ARMED FORCES ACADEMY}

The specific features of the specialized military language and the nature of communication within the military have a great influence on the language teaching/learning process at the AFA. The rather formal classroom atmosphere has a particularly negative impact on improving English, Russian, and German communication skills. Young cadets are hesitant to work in pairs, they do not actively engage in discussions and conversations, they are typically not spontaneous nor creative. Most of the conventional language teaching methods are not suitable for the military environment, a personalized approach and modified solutions are necessary.

The most important factors affecting the language education within the AFA include the rank (e.g. in case of an inhomogeneous group, the lower-rank soldiers manifest unwillingness to cooperate; high-ranking commissioned officers tend to disrupt the classes with frequent questions or remarks), study program/specialization, (future) posting, eventual future deployment in a foreign country, present circumstances of the language classes (previous classes, e.g. if a physical training class precedes the language class, cadets tend to be physically exhausted and do not engage actively in the process, thus passive learning activities are recommended), etc. Unlike young cadets, generally speaking, commissioned officers are critical thinkers with intristic motivation, who need to know the purpose of their learning process, they are autonomous learners skeptical towards the presented ideas and the best way for them to acquire knowledge is through their own experience and while solving problems (Raviv 2013).

The linguistic features of the military language are based on the rules, standards and conventions of communication within the military, which are typically drilled by the cadets right after they join the army. Morpho-syntactic specificities have to be drilled so that they become a routine. The "previously rehearsed patterns of action" (Mälkki K., Mälkki J. 2013) are an integral part of every cadet's education and training. This pattern reminds strongly of the Audio-Lingual Method ${ }^{3}$. This method, which is based on the typically military drill and response to form new habits of the language, has been dubbed the Army Method. Its other name fits the method accurately, since it reflects its military roots - the U.S. military's need during WWII to train large volumes of personnel in disparate languages and the pattern of mechanical habit-formation activities (with little opportunities for mistakes). The method's other typical features include teacher-centered lessons, focus on structural linguistics that emphasized grammatical structure, equal importance not given to all four skills, focus on memorization rather than functional learning, repetition drills, chain drills, drills, drills, and more drills etc. While the method was questioned and discredited by many prominent linguists, foremostly by Noam Chomsky, and practically stopped being used in foreign language teaching processes the way it used to be in the $50 \mathrm{~s}$ and $60 \mathrm{~s}$, its characteristics overlap to a large extent with the nature and characteristics of the military language and communication. Against this background, the following can be concluded: the methods used in foreign language teaching/learning within the military environment must reflect the particularities of the specialized military language in order to be effective; a large amount of study material cannot be found in any students' books nor textbook, which means it has to be compiled by individual teachers, implying the need for highly educated (both in linguistics as well as military matters) teaching staff.

\section{SCHOLAR-SOLDIER}

After the end of the Cold War, a new concept of the military officer emerged. The so-called scholar-soldier shall serve supranational purposes and be both: a well-trained soldier and a highly educated graduate (Paile 2013). The two models of military training and education - the Spartan model (focus on military training and field exercises) and the Athenian model (focus on academic education and knowledge; military officers as intellectual elites) shall merge and form the ideal model. "During the Cold War and its immediate aftermath, many believed that foreign language skills and

\footnotetext{
${ }^{3}$ The Audio-Lingual Method is a method in teaching foreign languages based on behaviorist theory, i. e. the belief that people can be trained through reinforcement. Widely used in the 1950s and 1960s, the method became discredited by many scientists, especially by the famous Noam Chomsky and it fell from popularity.
} 
regional expertise were only required by a very small segment of the force, usually serving in fairly specialized jobs."(Carey 2008, 5). This notion has been proven wrong. The security policy issues particularly since the 1990s make it obvious, that the world needs military officers trained and educated complexly, which includes (not least) the foreign language skills.

Major Kenneth Carey, Brigade S2, 1st BCT, 1st CAV, stated: "If all our soldiers spoke Arabic we could have resolved Iraq in two years. My point is that language is obviously an obstacle to our success, much more so than cultural. Even a fundamental understanding of the language would have had a significant impact on our ability to operate." This is a very strong statement, which should be taken into account and addressed by authorities of military training and educational institutions. Pedagogical staff at military academies and institutions have been modifying the curricula and adapting them to the current needs, reflecting the geopolitical changes and asymmetric threats. In spite of this, the language study advocates in general complain about the lack of scientific and academic attention to foreign languages within the military. This holds particularly true for the foreign teachers at the AFA, who strive to raise awareness to the problems caused by lack of foreign language knowledge and promote the importance of foreign language skills within the military.

\section{CONCLUSIONS}

Based on the several decades of foreign teaching experience along with the observation of the learning process and communication of military personnel we can conclude that the military language education differs greatly from the language education in the civilian environment. Lack of linguistic research in the military makes it hard to reflect these differences and to apply the conventional teaching/learning methods in the military language classes. A tailor-made solution is necessary, i.e. individualized approach in teaching, methods carefully selected and modified for the military personnel, further research and development in the field of foreign language for military purposes.

The aim of the AFA is to develop military leaders of character, able to work in national as well as international security environments. Their foreign language education shall make sure that they develop reading, listening, writing and communication skills necessary to perform their duties effectively, to be able to interact with the international military environment, engage in lifelong learning process, and be an equal partner of soldiers of other NATO armies. Regarding this last point, the foreign language skills of Slovak military personnel in the European and NATO context are rather below average. We see a lot of room for improvement, including more focus on language lessons within the education process of the cadets, more focus on building intristic motivation in cadets and officers, enhancement of teaching methods (e.g. modernization of language labs, using modern technologies in classes, regular further education programs for teachers etc.), a closer cooperation with foreign partner academies and military institutions and many other achievable objectives. To keep pace with the NATO and EU policies and trends regarding language skills, Slovakia has to take a critical look at its shortcomings in language education on all levels, starting from elementary schools up to university level. Every effort should be made to support multilingualism in Slovak military personnel, to train and educate complex scholar-soldiers for the maintenance and defense of national and international security.

\section{REFERENCES}

Army Culture and Foreign Language Strategy. 2009. Accessed January 2, 2021 https://www.army.mil/article/156304/linguists_serve_vital_purpose_to_armys_worldwide_mission

Crossey, Mark. 2005. Improving Linguistic Interoperability. Accessed January 2, 2021. https://www.nato.int/cps/en/natohq/opinions_22033.htm

Orban, Leonard. 2007. European Day of Languages - Press Conference. Accessed January 2, 2021. https://ec.europa.eu/commission/presscorner/detail/en/SPEECH_07_568 
Orban, Leonard. 2007. European Day of Languages - Press Conference. Accessed January 2, 2021. https://ec.europa.eu/commission/presscorner/detail/en/SPEECH_07_568

Multilingualism - an asset and a shared commitment. 2008. Accessed January 2, 2021. https://ecspm.org/wp-content/uploads/2016/04/EU-Multilingualism-Policy_2008.pdf

Valdes, Guadalupe. Multilingualism. 2021. Accessed January 2, https://www.linguisticsociety.org/ resource/multilingualism

Slater, Ariane. 2015. "Militärsprache. Die Sprachpraxis der Bundeswehr und ihre geschichtliche Entwicklung“. Rombach Verlag KG. Freiburg i. Br./Berlin/Wien

Dauber, Cori. Accessed March 10, 2021. https://www.encyclopedia.com/history/encyclopedias-almanacstranscripts-and-maps/language-military-official-terminology

Raviv, Amira. 2013. "Developing Senior Leaders, Challenges, Methodologies, and Dillemas". Studies for Military Pedagogy, Military Science \& Security Policy 12; Thinking and Acting in Military Pedagogy. Peter Lang $\mathrm{GmbH}$, Internationaler Verlag der Wissenschaften

Mälkki, Kaisu, Mälkki, Juha. 2013. "Preparing to Experience the Unexected - The Challenges of Transforming Soldiership". Studies for Military Pedagogy, Military Science \& Security Policy 12; Thinking and Acting in Military Pedagogy. Peter Lang $\mathrm{GmbH}$, Internationaler Verlag der Wissenschaften, 41.

Paile, Sylvian. 2013. "Towards a European Understanding of Academic Education of the Military Officers?". Studies for Military Pedagogy, Military Science \& Security Policy 12; Thinking and Acting in Military Pedagogy. Peter Lang GmbH, Internationaler Verlag der Wissenschaften.

Carey, Kenneth. 2008. Building Language Skills and Culture Competencies in the Military: DOD's Challenge in Today's Educational Environment. 2008. 5. 